IZA DP No. 2459

\title{
Are the French Happy with the
} 35-Hour Workweek?

Marcello Estevão

Filipa Sá

November 2006 


\title{
Are the French Happy with the 35-Hour Workweek?
}

\author{
Marcello Estevão \\ International Monetary Fund
}

Filipa Sá

MIT and IZA Bonn

Discussion Paper No. 2459
November 2006

\author{
IZA \\ P.O. Box 7240 \\ 53072 Bonn \\ Germany \\ Phone: +49-228-3894-0 \\ Fax: +49-228-3894-180 \\ E-mail: iza@iza.org
}

Any opinions expressed here are those of the author(s) and not those of the institute. Research disseminated by IZA may include views on policy, but the institute itself takes no institutional policy positions.

The Institute for the Study of Labor (IZA) in Bonn is a local and virtual international research center and a place of communication between science, politics and business. IZA is an independent nonprofit company supported by Deutsche Post World Net. The center is associated with the University of Bonn and offers a stimulating research environment through its research networks, research support, and visitors and doctoral programs. IZA engages in (i) original and internationally competitive research in all fields of labor economics, (ii) development of policy concepts, and (iii) dissemination of research results and concepts to the interested public.

IZA Discussion Papers often represent preliminary work and are circulated to encourage discussion. Citation of such a paper should account for its provisional character. A revised version may be available directly from the author. 
IZA Discussion Paper No. 2459

November 2006

\section{ABSTRACT}

\section{Are the French Happy with the 35-Hour Workweek?*}

Legally mandated reductions in the workweek can be either a constraint on individuals' choice or a tool to coordinate individuals' preferences for lower work hours. We confront these two hypotheses by studying the consequences of the workweek reduction in France from 39 to 35 hours, which was first applied to large firms in 2000. Using the timing difference by firm size to set up a quasi-experiment and data from the French labor force survey, we show that the law constrained the choice of a significant number of individuals: dual-job holdings increased, some workers in large firms went to small firms where hours were not constrained, and others were replaced by cheaper, unemployed individuals as relative hourly wages increased in large firms. Employment of persons directly affected by the law declined, although the net effect on aggregate employment was not significant.

JEL Classification: E24, J22, C21

Keywords: workweek, coordination, job-sharing, welfare

Corresponding author:

Filipa Sa

MIT Department of Economics

50 Memorial Drive

Cambridge MA 02142-1347

USA

E-mail: fgsa@mit.edu

\footnotetext{
* We thank Joshua Angrist, David Autor and Olivier Blanchard for insightful discussions and comments. Dora Costa, Luc Everaert, Giuseppe Moscarini, Andrei Shleifer, and seminar participants at MIT, the IMF, the Yale School of Management Behavioral Science Conference, the Bank of England, the 2006 EALE Conference, and the 9th IZA European Summer School in Labor Economics provided valuable suggestions. Filipa Sá acknowledges financial support from the Portuguese Science and Technology Foundation through a Ph.D. fellowship.
} 


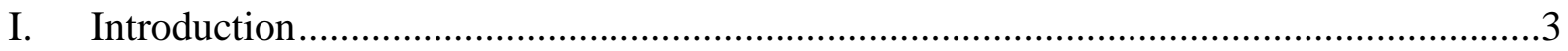

II. Institutional Background and Previous Research .................................................4

III. Consequences of Hours Restrictions: Theory ..............................................................

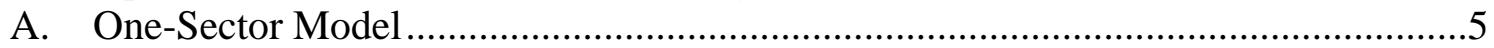

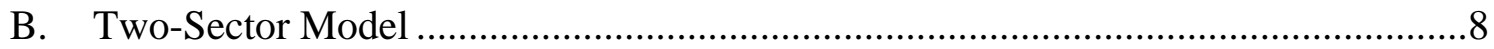

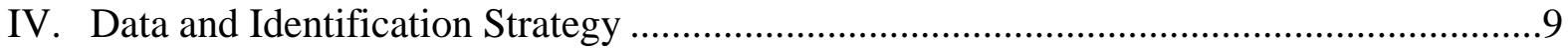

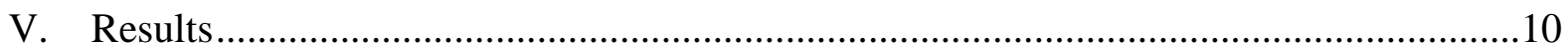

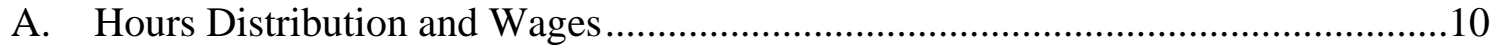

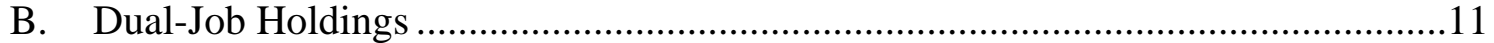

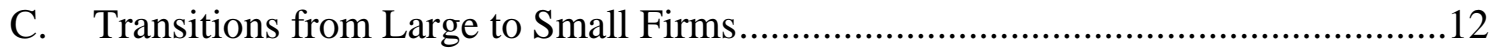

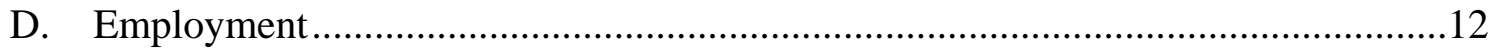

E. Satisfaction with Hours of Work .................................................................14

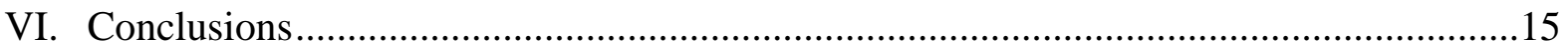

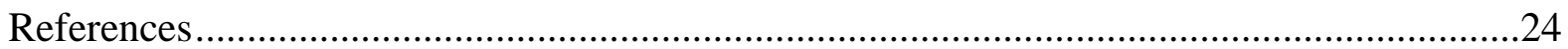

Tables

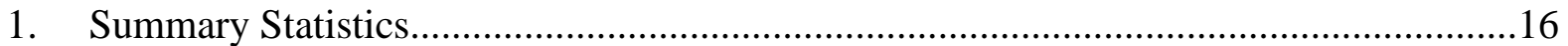

2. Distribution of Usual Weekly Hours ........................................................................16

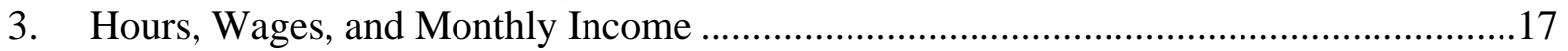

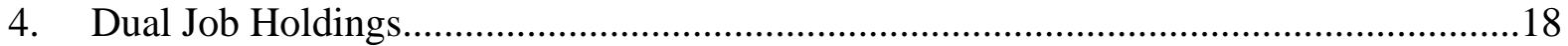

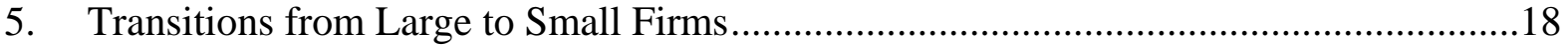

6. Usual Weekly Hours for Workers Who Move from Large to Small Firms.....................19

7. Transitions from Employment to Unemployment ........................................................19

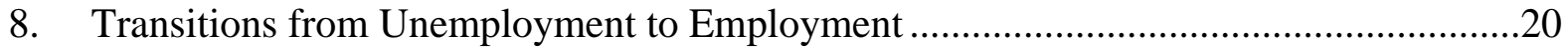

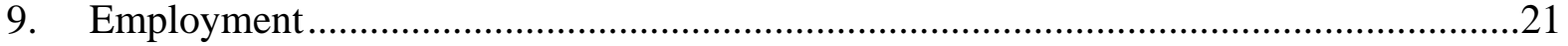

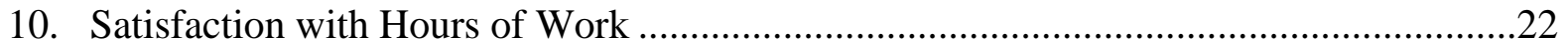

Figures

1. Annual Hours Worked per Person Employed...........................................................23

2. Log Employment Probabilities by Firm Size............................................................23 


\section{INTRODUCTION}

Hours of work have declined steadily in Europe compared with the United States and Japan since the 1970s (Figure 1). While in the 1960s annual hours per person employed in France were the same as in the United States, they are now much smaller, and the same pattern can be observed in other European countries. In fact, today the average American works approximately 400 hours more per year than the average European. The reasons for this reduction have been a topic of recent debate. ${ }^{2}$ Alesina et al. (2005) provide some evidence that labor market regulations and unionization are key factors behind such a difference. They raise an interesting point: "A very hard question to answer is whether labor unions and regulations introduce distortions that reduce welfare or whether they are a way of coordinating on a more desirable equilibrium with fewer hours worked” (p. 2). They argue that, if there are complementarities in leisure activities, the "social multiplier effect," everyone would benefit from a coordinated reduction in working time.

This paper looks at the benefits of coordinated workweek reductions with a focus on France. Since the 1980s, a sequence of laws has reduced the workweek in France. The law enacted in 1998 mandated a reduction of the workweek to 35 hours in large firms by 2000 and in small firms by 2002. The purpose of this reduction was to increase employment through work sharing, as the government expected that a given amount of work would be divided by a larger number of employees - an argument commonly known as the "lump of labor" fallacy. Implicitly, the government assumed this policy would be welfare enhancing as the benefits from reducing unemployment (because of higher individual self-esteem, lower fiscal deficits, and, maybe, higher output) would offset welfare losses from possibly constraining firms' and workers' workweek decisions. Besides, the workweek reduction could have worked as a coordination mechanism to a better social outcome if there were complementarities in leisure, motivated by the desire to spend weekends or holidays with other people or by the decrease in the social stigma of having more leisure.

We explore the firm size-specific timing of these laws, which generated useful heterogeneity in the population of affected individuals and firms, to evaluate the effects of the coordinated workweek reduction. Using data from the French Labor Force Survey and matched information for firm size from SIRENE, a firm-level survey, individuals were classified as part of the experiment group if working in large firms and of the control group if working in small firms. The micro database also permits controlling for individual characteristics and business-cycle effects. The latter are particularly important because strong economic growth and other labor market reforms of the early and mid-1990s boosted aggregate French employment in the second half of the 1990s and beginning of the 2000s. We are not aware of any study that explores such heterogeneity to evaluate the impact of the law on workers' welfare while at the same time controlling for key aggregate and individual effects.

The paper shows that the 35-hour workweek law does not appear to have coordinated people’s preference for lower work hours, as a significant fraction of individuals changed

\footnotetext{
${ }^{2}$ See, among other studies, Blanchard (2004), Prescott (2004), and Alesina et al. (2005).
} 
their behavior to circumvent its effects. First, many people working in large firms tried to maintain their initial workweek by securing a second job and obtained an increase in hourly wage, possibly to be compensated for the workweek reduction. Moreover, the flow of workers from large firms into small firms and unemployment also increased. While these flows could represent voluntary quits, as constrained work hours reduce the utility of working in large firms, they are also consistent with firings due to increased cost from lower “cheap” hours (i.e., hours paid at normal rates without overtime premium) and higher hourly wages. In both cases, a significant fraction of large firm employees were hurt. As a counterpart of these outflows, the paper documents that the law increased inflows to large firms from the unemployment pool, suggesting a significant rise in job turnover rates. We also provide some evidence that the workweek law left employment levels in large firms unchanged, suggesting that it failed in its key mandate: to increase employment levels. Finally, evidence using the Eurobarometer database shows that, on average, French workers did not become more satisfied with their hours of work after the reduction in the workweek relative to other Europeans. ${ }^{3}$

The next section describes the legal background. Section III presents a model with a restriction in hours and complementarities in leisure. Section IV describes the data and the empirical strategy. Section V explains the empirical findings. Section VI concludes.

\section{INSTITUTIONAL BACKGROUND AND PREVIOUS RESEARCH}

The workweek in France has been shortened by a sequence of laws since the early 1980s. In 1982, François Mitterrand's socialist government reduced the length of the workweek from 40 to 39 hours. In 1998, a new socialist government further reduced the workweek to 35 hours. Two laws implemented the latest workweek reduction: (i) Aubry I (June 1998), set the length of the workweek at 35 hours, beginning in February 2000 for firms employing more than 20 people, and in January 2002 for smaller firms; (ii) Aubry II (January 2000) introduced more detailed legal provisions regarding overtime. To ease the transition for small firms, the law reduced their overtime premium and increased their annual limit to overtime work compared with large firms. This way, small firms could continue operating on a 39hour basis paying the difference with a reduced overtime premium.

The purpose of the workweek reduction was to create more jobs during a period of high unemployment (11.5 percent in 1998). Employees were expected to bear a small part of the cost of the working time reduction, continuing to earn roughly the same monthly income-in line with the unions' slogan "35 hours pays 39." To attenuate the deleterious effects on profitability, the government conceded rebates on firms' social security contributions depending on employees' characteristics. The rebate declined with the employee's monthly income and was largest for individuals receiving the minimum wage. In addition, unions accepted a more flexible accounting of overtime work from a weekly to an annual basis and the working time reduction was expected to increase productivity. The official argument was

\footnotetext{
${ }^{3}$ It is important to note, though, that a complete evaluation of the 35-hour workweek laws would include their longer-term effects, which would require a longer data series.
} 
that productivity increases together with cuts in social security contributions might even lead to a reduction in the cost of labor, so that firms would not need to cut monthly wages for the policy to be sustainable. To protect low-wage individuals, the law guaranteed the monthly earnings of workers receiving the minimum wage (SMIC, "salaire minimum interprofessionnel de croissance”).

Some studies look at the effects of workweek reductions on employment and labor costs. Crépon, Leclair, and Roux (2005) use firm-level data to estimate the effect of the 35-hours mandate on productivity, the cost of labor, and employment. They compare the performance of firms that reduced the workweek to 35 hours relative to those that remained on the 39hours schedule. They find that total factor productivity decreased by 3.7\% from 1997 to 2000 in firms that reduced the workweek relative to those that did not. At the same time, employment increased by $9.9 \%$ in firms who adopted the 35-hours schedule. Crépon and Kramarz (2002) study the employment effects of an earlier law: the 1982 reduction in the workweek from 40 to 39 hours. They explore the variation in hours worked to design a quasiexperiment. They find an increase in the probability of making a transition from employment to unemployment between 2.3 and 3.9 percentage points. They do not measure the net effect on employment. For Germany, Hunt (1998 and 1999) studies the employment effects of restrictions in hours exploring the cross-industry variation in reductions in standard hours. She finds that the reductions in hours decreased employment in the period 1984-94.

In this paper we take a broader approach and look at the effects of the workweek reduction on several margins_-all closely related to workers' welfare_-instead of focusing almost exclusively on the employment of people directly affected by the law. We use information on dual-job holdings, wages, employment and transitions from large to small firms to test whether the reduction in hours increased welfare or introduced distortions to workers' choices, forcing them to work less than their desired hours.

\section{CONSEQUENCES OF HOURS RESTRICTIONS: THEORY}

In this section we present a model to guide the empirical work on the consequences of the 35-hours workweek law on employment and job satisfaction. We start with a one-sector model and look at the effects of an upper bound on hours on employment, wages and happiness. Then, we extend the model to two sectors, one covered by the restriction in hours and another with free choice of hours.

\section{A. One-Sector Model}

On the supply side, we introduce complementarities in leisure. ${ }^{4}$ Utility is separable in consumption and leisure:

$$
U\left(w H_{i}\right)+V\left(1-H_{i}, 1-\hat{H}\right)
$$

\footnotetext{
${ }^{4}$ The labor supply side of the model is an application of the general framework developed by Cooper and John (1988).
} 
$H_{i}$ is the number of hours worked by representative worker $i, \hat{H}$ is the number of hours worked by all other workers, and $w$ is the hourly wage. Utility is concave in consumption and leisure, $U_{11}<0, V_{11}<0$. The labor supply of representative worker $i$ is given by his best response to the hours worked by others, given the wage. It comes from the solution to the utility maximization problem:

$$
\max _{H_{i}} U\left(w H_{i}\right)+V\left(1-H_{i}, 1-\hat{H}\right)
$$

The first order condition is:

$$
w U^{\prime}\left(w H_{i}\right)-V_{1}\left(1-H_{i}, 1-\hat{H}\right)=0
$$

Solving this equation for $H_{i}$ gives the labor supply of worker $i$, given the wage and the hours chosen by other workers, $H_{i}^{*}=H^{*}(w, \hat{H})$. The derivative of the supply function with respect to the wage depends on the usual substitution and income effects. We assume that the substitution effect dominates and labor supply is increasing in the wage. The derivative with respect to $\hat{H}$ is given by $\rho=-\frac{V_{12}}{w^{2} U^{\prime \prime}+V_{11}}$. The denominator is negative because of the assumptions of concavity of the utility function. The condition for labor supply to be increasing in the hours supplied by other workers is $V_{12}>0$. This means that there are positive strategic complementarities in leisure, i.e., the marginal utility of leisure increases if other workers have more leisure. This can be justified if workers enjoy leisure more when they can have their friends' company or if the social stigma of working less is smaller when everyone is working less. ${ }^{5}$

We focus on symmetric Nash equilibria, where everyone is working the same number of hours, $H_{i}^{*}=H^{*}(w, \hat{H})=\hat{H}$. If the supply function intersects the 45 degree line only once, there is a unique Nash equilibrium. This is the case of weak complementarities in leisure. With strong complementarities in leisure, there will be multiple equilibria, as illustrated in Diagram 1. The condition for multiple equilibria is that $V_{12}+w^{2} U^{\prime \prime} \geq-V_{11}$. Multiple equilibria are more likely if the utility function is not very concave ( $U^{\prime \prime}$ and $V_{11}$ not very large) and if there are large complementarities in leisure ( $V_{12}$ large). When, in addition to positive complementarities, there are positive spillovers in leisure, so that $V_{2}\left(1-H_{i}, 1-\hat{H}\right)>0$, a coordinated reduction in hours increases the utility of all workers.

\footnotetext{
${ }^{5}$ Clearly, there may also be negative complementarities in leisure. For instance, beaches get crowded during summer vacations and some people would choose to stay longer at home only if their neighbors don't.
} 


\section{Diagram 1}

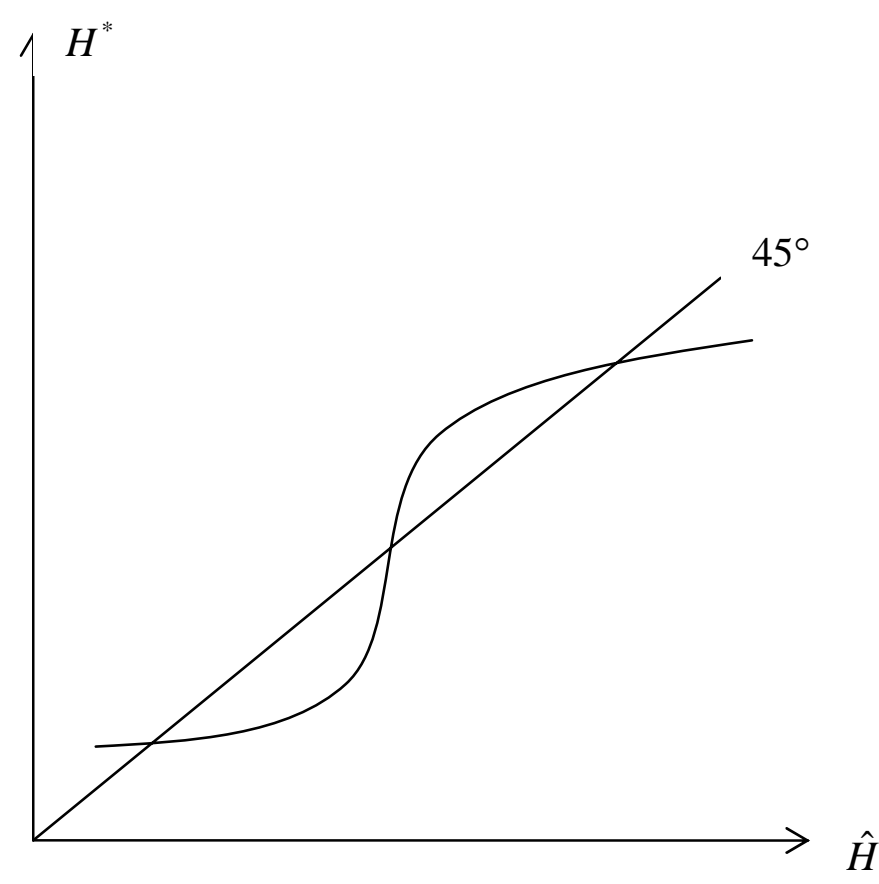

To see how this works, we look at a symmetric cooperative equilibrium, that is, an action for all workers that maximizes the utility of the representative worker. This is given by the solution to the maximization problem:

$$
\max _{\hat{H}} U(w \hat{H})+V(1-\hat{H}, 1-\hat{H})
$$

The first order condition is:

$$
w U^{\prime}(w \hat{H})-V_{1}(1-\hat{H}, 1-\hat{H})-V_{2}(1-\hat{H}, 1-\hat{H})=0
$$

By the envelope theorem $w U^{\prime}(w \hat{H})-V_{1}(1-\hat{H}, 1-\hat{H})=0$, as individuals actually maximize their utility taking other people's actions as given, and the socially optimal workweek decision is not taken. If there are positive spillovers in leisure $\left(V_{2}>0\right)$, equilibria with lower hours would be preferred instead and the 35-hours mandate would be a solution to a coordination failure. In summary, in the absence of a coordination mechanism, workers would choose to work too many hours relative to the social optimum.

On the demand side, we assume that hours and workers are perfect substitutes in the production function $Y=F(H N, K)$. There is a fixed cost of employment, $a$, which 
represents labor costs that are not sensitive to variations in hours of work (e.g. training, daycare provision, and other benefits). The cost of labor is given by $a N+w H N$. We first assume that output is fixed and, at the initial symmetric Nash equilibrium, workers work $\bar{H}_{0}$ hours. We also assume for simplicity that firms cannot contract overtime. After a reduction in the standard workweek to $\bar{H}_{1}<\bar{H}_{0}$, firms reduce hours to $\bar{H}_{1}$ and increase employment to keep output constant. In this case, a reduction in standard hours increases employment.

If firms can adjust output, there is a negative scale effect. Because part of the labor costs do not depend on hours worked, the reduction in standard hours increases the cost of labor for the same number of hours hired. The scale effect implies a reduction in output, reducing hours and employment. Also, firms may respond to the increase in the cost of labor by substituting capital for labor. Thus, the net effect on employment may not be positive. In addition, if the productivity gains expected by the French government did materialize, it would be even less likely that the reduction in hours would increase employment. With a higher productivity, firms would be able to produce more without increasing the labor force by as much as the reduction in hours. ${ }^{6}$

\section{B. Two-Sector Model}

Because our empirical strategy explores the different implementation timing of the 35-hours mandate in large and small firms, it is useful to extend the model to allow for two sectors: one covered by the law (large firms), and one with free choice of hours (small firms). Labor supply and labor demand are as described above for the one-sector model.

Under the assumptions of perfect substitutability between hours and workers and fixed output, employment in the covered sector increases proportionally to the reduction in hours. If there are positive complementarities in leisure, workers in the covered sector are happier. Workers would want to move from small to large firms. By a compensating differentials argument, wages in large firms may decrease relative to small firms. Because workers in small firms are working a less desirable number of hours, their relative wages may have to increase so that they don't leave to large firms.

Without positive complementarities in leisure, workers in large firms are forced to work less than they would prefer. They may respond by moving to the uncovered sector or by looking for a second job ${ }^{7}$. The wage in large firms may increase relative to small firms to compensate individuals for working undesirably low hours.

\footnotetext{
${ }^{6}$ Freeman (1998) gives an interesting discussion of the demand-side and supply-side responses to restrictions in hours.

${ }^{7}$ Another possible response if workers are constrained by the 35-hours mandate is to become self-employed. We looked at the effect of the law on transitions from employment to self-employment and found no effect. This is not surprising, given that the decision to be self-employed involves many considerations other than the workweek size.
} 


\section{DATA AND IDENTIFICATION STRATEGY}

We use data from the French labor force survey (Enquête Emploi) from 1993 to 2000. The sample is renewed by a third every year. Because we want to measure the effect of the law on workers' behavior, classification in the control and treatment groups needs to be done before the law was enacted and the response to the law needs to be measured after the enactment. As the law was approved in June 1998 and the labor force survey is conducted every year in March, the last panel in our database, 1998-2000, fulfills this condition. The period before the law covers the years 1993 to 1998 and the period after covers 1999 and 2000. It may be that employees do not change behavior in 1999 as they may not have had enough time to adjust. This would bias our results towards underestimating the effect of the law. We take a conservative approach and see if we find a significant effect already in 1999.

In a first stage, the reduction in hours was compulsory only for firms with more than 20 employees, although small firms received incentives to reduce the length of the workweek before the legal deadline. In any case, as we shall see in the next section, the reduction in hours worked was much faster in large firms. Our specifications explore this difference between small and large firms ${ }^{8}$, using data on firm size from matched firm-level data from the French Registry of Firms, SIRENE.

The empirical work is based on reduced-form equations of the type:

$$
E\left(y_{i t}\right)=\Phi\left(\alpha+\gamma d_{t}+\beta X_{i 0}+\delta_{0} \text { treat }_{i}+\delta_{1}(\text { treat } \times \text { post1999 })_{i t}\right)
$$

$y_{i t}$ is the outcome of interest for individual $i$ at year $t . X_{i 0}$ is a set of controls in the year when the individual entered the panel. The usual set of controls includes gender, marital status $^{9}$, an interaction of gender and marital status, number of children less than 6 years of age, an interaction of gender and number of children less than 6 , age and age-squared , tenure, region dummies, and education. $d_{t}$ are year effects. treat ${ }_{i}$ is an indicator variable equal to 1 if the individual belongs to the treatment group and 0 otherwise. Table 1 reports descriptive statistics by hours worked, firm size and year for key individual characteristics. In most specifications, the control group includes employees working in small firms and the treatment group includes employees working in large firms. Firms with fewer than 20 employees are classified as "small", while firms hiring between 20 and 49 employees are "large". We impose a cutoff at 49 employees to ensure more homogeneity between the treatment and control groups. ${ }^{10}$ In some specifications we also explore the variation across

\footnotetext{
${ }^{8}$ Kugler and Pica (2005) adopt a similar identification strategy to identify the employment effect of the increase in unjust dismissal costs for firms below 15 employees in Italy in 1990. The variation by firm size is also used in Acemoglu and Angrist (2001) to examine the employment consequences of the American with Disabilities Act.

${ }^{9}$ Marital status is an indicator equal to 1 if the individual has a partner who lives in the same household, even if he is not legally married, and 0 otherwise.

${ }^{10}$ Our results are not sensitive to the choice of the cutoff on firm size.
} 
individuals working different hours, as in Crépon and Kramarz (2002). Because the restriction in hours did not bind for individuals already working 35 hours or less before the law, they were not affected by it and could serve as a control group. We compare their behavior to that of workers who were working more than 35 hours before the law.

The coefficient $\delta_{1}$ is the difference-in-differences (DD) estimator measuring the impact of the law on the outcome variable. In most specifications, the standard errors are corrected for clustering on year/firm size. The sample is limited to employees aged 15 to 64 with positive net monthly income, and self-employed individuals are excluded.

This strategy requires fairly weak identifying assumptions. It requires that there are no contemporaneous shocks, other than the workweek reduction, affecting the labor supply outcomes of the control and treatment groups. If this assumption holds, the behavior of workers in the control group gives information about how workers in the treatment group would have behaved if there had been no reduction of the workweek.

There is one element that may bias our results. If the business cycle affects small and large firms differently, our estimates may be capturing the effect of the business cycle instead of the effect of the reduction in hours. The French economy was booming in the early 2000s, and the unemployment rate decreased by about two percentage points from 1999 to 2001. If there is a firm-size specific business cycle effect, our estimates may be biased. To control for this, we follow the strategy in Kugler and Pica (2005) and estimate the following alternative specification, in which $G D P_{t}$ is the growth rate of real GDP and the extra interaction term captures firm-size specific business cycle effects:

$$
E\left(y_{i t}\right)=\Phi\left(\alpha+\gamma d_{t}+\mu\left(G D P_{t} \times \text { treat }_{i}\right)+\beta X_{i 0}+\delta_{0} \text { treat }_{i}+\delta_{1}(\text { treat } \times \text { post1999 })_{i t}\right)
$$

\section{REsults}

\section{A. Hours Distribution and Wages}

The 35-hours mandate had a clear impact on weekly hours of work, as shown in Table 2. In 1999 most employees were working 39 hours. After the law, there was a big increase in the proportion of employees working 35 hours, led by large firms. In 2002 more than 45 percent of employees in large firms and almost 35 percent of employees in small firms worked on a 35-hour basis.

To examine more carefully the effect of the workweek reduction law on hours worked, we estimate equation (6) with hours in the main job as the dependent variable. We look separately at workers receiving between $10 \%$ below and $10 \%$ above the minimum wage and workers receiving between $10 \%$ and $80 \%$ above the minimum wage. We are interested in this distinction because the law mandated that the monthly earnings of workers receiving the minimum wage should stay constant. Therefore, it is important to separate these two 
subsamples when looking at the effect of the law on hours and wages. ${ }^{11}$ The control group is "employees in small firms" and the treatment group is "employees in large firms". The estimation results are reported in the first column of Table 3. The DD estimators are significant and negative, suggesting that the law reduced hours worked in large firms relative to small firms. The results do not change significantly when we control for firm-size specific business cycle effects. The impact of the reduction of the workweek on hours seems to be too small (around 20 to 30 minutes, compared with the legal reduction of 4 hours). This is because we are looking at all employees and not just those working full time. Moreover, working time includes overtime and workers tend to report the time they spend at the workplace instead of the hours that they effectively work.

Hourly wages increased in large firms vis-à-vis the values paid by small firms both for workers at and above the minimum wage. Monthly incomes increased slightly for workers at the minimum wage and did not change for workers above the minimum wage. ${ }^{12}$ Again, the results do not change when we control for firm-size specific business cycle effects. The increase in wages in large firms relative to small firms is consistent with workers' demands and could be interpreted as compensation for working undesirably low hours. We need to be careful about this interpretation because there are institutional factors that introduce wage rigidities in France, in particular the labor unions. But the increase in wages in large firms relative to small firms is a first indication that, on average, workers may not have been happier with the workweek reduction. We conjecture that in the absence of wage rigidities the wage adjustment would have been even larger.

\section{B. Dual-Job Holdings}

We explore the variation across firm size and across individuals working different hours to study the effect of the law on the proportion of workers with more than one job. The treatment group is "individuals working more than 35 hours" at the beginning of each panel. The control group is "workers working 35 hours or less" at the beginning of each panel. We compare the behavior of the treatment and control groups before and after the law in large firms (experimental) and small firms (non experimental). By exploring two sources of variation (the size of the firm and the length of the workweek) we increase the chance that the effect found in the estimation procedure is driven by the workweek reduction law. We run the following linear probability model: ${ }^{13}$

\footnotetext{
${ }^{11}$ We exclude workers with earnings above $80 \%$ of the minimum wage because we want to ensure more homogeneity across individuals in the two categories. Moreover, the law gave more flexibility in the negotiation of hours and earnings to workers in managerial positions, and these workers are more likely to be at the top of the earnings distribution.

12 The results are insensitive to estimation with individual fixed effects to account for unobservable heterogeneity.

${ }^{13}$ In this and the following sections the results do not change significantly if we use either a probit or a logit specification instead of the linear probability model described in (8).
} 


$$
\begin{aligned}
& E\left(\text { dual }_{i t}=1\right)=\alpha+\gamma d_{t}+\beta X_{i 0}+\delta_{0} l \text { arg } e_{i}+\delta_{1} \text { treat }_{i}+\delta_{2}\left(l \arg e \times p_{0} t 1999\right)_{i t}+ \\
& \delta_{3}(\text { treat } \times \text { post } 1999)_{i t}+\delta_{4}(l \text { arg } e \times \text { treat })_{i}+\delta_{5}(l \arg e \times \text { treat } \times \text { post } 1999)_{i t}
\end{aligned}
$$

The coefficient on $l$ arg $e \times$ treat $\times$ post1999 is a triple-difference estimator (DDD) and captures the effect of the reduction of the workweek on dual job holdings. Table 4 reports the results. The law increased dual job holdings by 3.3 percentage points. This effect is quite large given the small proportion of workers with a second job in France and does not change significantly when we control for firm-size specific business cycle effects.

\section{Transitions from Large to Small Firms}

If workers in the covered sector are forced to work less than they desire, they may move to the uncovered sector. To test this, we look at employees working in large firms and compare the transitions to small firms of those who were working more than 35 hours (treatment group) relative to those who were working 35 hours or less (control group) before the law. We use the following specification, in which small $_{i t+2}$ is equal to 1 if the worker was working in a large firm at time $t$ and works in a small firm at time $t+2$ and 0 if he stays in a large firm, and treat $_{i}$ comprises employees working more than 35 hours at time $t$ :

$$
E\left(\text { small }_{i t+2}=1\right)=\alpha+\gamma d_{t}+\beta X_{i t}+\delta_{0} \text { treat }_{i}+\delta_{1}(\text { treat } \times \text { post1999 })_{i t}
$$

The results are reported in Table 5. The law increased transitions from large to small firms by about 1.2 percentage points.

To check whether the increased transitions from large to small firms are motivated by a desire to work more hours, we compare the working hours of individuals who made the transition from large to small firms with the hours of individuals who remained working in large firms. We use the following specification, where treat $_{i t}$ is equal to 1 if the individual was working in a large firm at time $t$ and in a small firm at time $t+2$ and 0 if he stayed in a large firm in through $t+2$ :

$$
E\left(\text { hours }_{i t+2}\right)=\alpha+\gamma d_{t}+\beta X_{i t}+\delta_{0} \text { treat }_{i}+\delta_{1}(\text { treat } \times \text { post1999 })_{i t}
$$

The sample is restricted to employees working more than 35 hours at time $t$ as those were

the ones directly affected by the law. The results, reported in Table 6, suggest that individuals who moved from large to small firms after the workweek reduction law work more hours than those who stayed in large firms.

\section{Employment}

To measure the effect of the law on transitions from employment to unemployment, we use the following specification:

$$
E\left(\text { unemp }_{i t+2}=1\right)=\alpha+\gamma d_{t}+\beta X_{i t}+\delta_{0} \text { treat }_{i}+\delta_{1}(\text { treat } \times \text { post } 1999)_{i t}
$$


We restrict the sample to employees working more than 35 hours in the base year as those were the ones directly affected by the law. The treatment group is "employees in large firms" and the control group is "employees in small firms" in the base year, i.e., the year in which they enter the panel. Equation (11) estimates the probability that they are employed or unemployed two years later. As seen in Table 7, transitions from employment to unemployment in large firms vis-à-vis small firms increased between 1.3 and 1.7 percentage points after 1999.

It is important to note that two alternative hypotheses could explain the joint result of an increase in relative hourly wages in large firms and the flow of employed individuals from large firms into small firms and into the unemployment pool. The first focuses on labor supply effects, consistent with the model developed in section III: as the workweek is reduced, workers in large firms face a more limited set of choices and either demand higher hourly wages to stay or quit working. In equilibrium, both effects are observed.

Alternatively, as relative hourly wages in large firms increased to compensate workers for a smaller workweek, costs could have risen and less productive employees fired. These individuals could, then, have found a job in smaller firms or remained unemployed. This alternative hypothesis singles out labor demand factors. Although the available data do not allow testing these alternative explanations, both are consistent with the law hurting many workers employed in large firms and working more than 35 hours before its implementation.

To see whether the law increased transitions from unemployment to employment, we test whether unemployed workers are more likely to find a job in large firms relative to small firms as a result of the restriction in hours by estimating a multinomial logit regression:

$E$ status $\left._{i t+2}=k\right)=\Phi\left(\alpha+\gamma d_{t}+\beta X_{i t}+\delta_{0}\right.$ unemp $_{i t}+\delta_{1}\left(\right.$ unemp $\left._{i t} \times{\text { post } 1999_{t}}\right)$ $+\delta_{2}\left(\right.$ unemp $_{i t} \times$ unemp less 1 year $\left.\left._{i t}\right)\right)$

status $_{i t+2}$ is equal to 1 if unemployed, 2 if employed in a large firm and 3 if employed in a small firm at time $t+2$. The independent variables are a set of time dummies, an indicator for unemployed at time $t$, an interaction of this variable with a post-1999 dummy, an interaction of unemployed with the duration of unemployment and the usual set of controls.

Table 8 reports the results taking the unemployed as the comparison group. Workers who were unemployed at time $t$ are likely to remain unemployed. When they find a job, they are more likely to work in a small firm than in a large firm. After 1999 there was an increase in the probability of making a transition from unemployment to employment. This increase was significantly larger in large firms than in small firms (we reject the equality of the

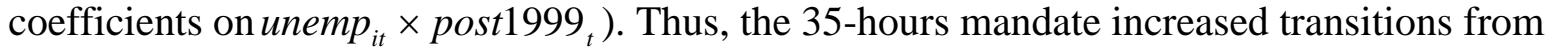
unemployment to employment. Workers who have been unemployed for less than a year are more likely to find a job and they are more likely to find a job in a large firm than in a small firm after the introduction of the law.

The evidence on transitions in and out of employment suggests that the 35-hours workweek law changed the composition of the labor force, as large firms replaced existing workers by 
cheaper outsiders. However, to measure the impact of the law on employment levels, it is important to look not only at transitions in and out of employment but also at the net effect on employment. Unfortunately, the data do not allow measuring the net effect on employment in a clear way: because we are comparing employees in large and small firms, they are, by definition, employed. Thus, we do not have a treatment and a control group. However, we can shed light on the net effect on employment by comparing the evolution over time of employment in small and large firms. We run the following multinomial logit regression, in which status ${ }_{i t}$ is equal to 1 if unemployed, 2 if employed in a large firm and 3 if employed in a small firm, and the independent variables are the usual set of controls and a dummy for the period after the law:

$$
E\left(\text { status }_{i t}=k\right)=\Phi\left(\alpha+\gamma p \text { ost } 1999_{t}+\beta X_{i 0}\right)
$$

Table 9 reports the results taking the unemployed as the comparison group. The probability of being employed relative to being unemployed increased after 1999, both in large and in small firms. The test for the equality of the two coefficients on post1999 does not reject the hypothesis of the two coefficients being equal. Thus, even though employment increased after the law, it did not increase more in large firms relative to small firms. This exercise suggests that the law did not increase employment, at least by March 2000. An alternative way to make the same point is to plot the log of the probability of working in a large or in a small firm divided by the probability of being unemployed. Figure 2 shows that the log odds of employment by firm size are essentially parallel, suggesting that the 35-hours mandate had no net effect on employment.

\section{E. Satisfaction with Hours of Work}

Another approach to see if the French are happier with the reduction in hours is to look at subjective measures of satisfaction with hours of work. Using data from the Eurobarometers of February/April 1996 and September/October 2001 we compare satisfaction with hours of work in EU countries in 1996 and 2001. ${ }^{14}$ This allows us to see whether the French became happier with their hours of work after the 35-hours workweek laws compared with other EU countries that did not have similar policies. Table 10 shows the results of an ordered probit regression of employees' satisfaction with hours of work. We introduce a dummy for France and for 2001 and an interaction of the two. There is no significant difference in the satisfaction of French employees with hours in 2001 compared with 1996 relative to other Europeans. Lower working hours do not seem to have made French workers happier than

\footnotetext{
${ }^{14}$ Satisfaction with hours of work is measured on a scale from 1 to 7 . The question from the Eurobarometer is: "I am going to read out a list of various aspects of jobs. Please choose between the two ends of this scale. If you are completely dissatisfied with that particular aspect of your present job, you give a score of 1 . If you are completely satisfied with that particular aspect of your present job, you give a score of 7 . The scores between 1 and 7 allow you to say how close to either side you are.” There is some skepticism about the quality of subjective measures of happiness and satisfaction. But, in most cases, friends and colleagues of the individual give ratings that are strongly related to the way people rate themselves, as reported in Diener and Suh (1999), and they provide some additional information on individuals’ welfare.
} 
other European citizens whose countries have not introduced workweek reduction legislation in the period.

\section{CONCLUSIONS}

The 35-hour mandate does not seem to have worked as a coordination mechanism to improve welfare because of possible positive complementarities in leisure. Exploring differences in implementation timing of the law by firm size, we find evidence that many employees in large firms, who were first affected by the reduction of the workweek, became more dissatisfied with their hours of work relative to employees in small firms. Our results show that the law increased the proportion of employees with more than one job and increased transitions from large to small firms. A raise in the relative hourly wages paid by large firms changed the composition of the labor force, with an increase in transitions in and out of employment, and an unambiguous decline in employment of individuals working 35 hours or more in large firms before the enactment of the law - the group directly affected by the law. This was not an intended purpose of the French government, who simply aimed at increasing employment. Our empirical strategy does not allow precisely measuring the net effect of the 35-hour workweek laws on aggregate employment, as we lack a control group. But, from looking at the evolution of employment in large and small firms, it seems that the law did not have a significant impact on aggregate employment.

In all fairness, we should recognize that our evaluation of the welfare effects of the 35-hours workweek is partial. We focus on revealed preferences and assess welfare effects based on observed changes in behavior. Therefore, we do not capture the increase in welfare of some workers who may have become better off as a result of the law because they would not have changed their behavior. However, our results cast serious doubts on whether the reduction in hours benefited French employees. Overall, our evaluation of the effects of the 35-hour workweek law is negative. It failed to raise aggregate employment and increased job turnover. Evidence from dual-job holdings, transitions from large to small firms, and subjective measures of satisfaction with hours of work consistently suggest that a significant share of the workforce was constrained by the workweek reduction. 
Table 1: Summary Statistics

\begin{tabular}{|c|c|c|c|c|c|c|c|c|}
\hline & \multicolumn{4}{|c|}{35 Hours or Less } & \multicolumn{4}{|c|}{ More than 35 Hours } \\
\hline & \multicolumn{2}{|c|}{ Large firms } & \multicolumn{2}{|c|}{ Small firms } & \multicolumn{2}{|c|}{ Large firms } & \multicolumn{2}{|c|}{ Small firms } \\
\hline & 1993-1997 & $1998-2000$ & 1993-1997 & $1998-2000$ & 1993-1997 & $1998-2000$ & 1993-1997 & $1998-2000$ \\
\hline \multirow[t]{2}{*}{ Percentage female } & 85.460 & 79.279 & 85.162 & 79.447 & 34.072 & 32.602 & 35.999 & 33.800 \\
\hline & $(35.257)$ & $(40.567)$ & $(35.550)$ & $(40.420)$ & $(47.397)$ & $(46.886)$ & $(48.000)$ & $(47.308)$ \\
\hline \multirow{3}{*}{$\begin{array}{l}\text { Average net monthly income } \\
\text { (francs) }\end{array}$} & & & & & & & & \\
\hline & 5671.961 & 5036.295 & 4578.945 & 4234.521 & 7922.348 & 9450.667 & 8526.168 & 9094.425 \\
\hline & $(21667.760)$ & $(5036.926)$ & (18968.900) & $(2621.242)$ & $(4645.550)$ & $(36615.400)$ & $(31722.900)$ & $(36429.050)$ \\
\hline \multicolumn{9}{|l|}{ Percentage with tenure less } \\
\hline \multirow[t]{2}{*}{ than 1 year } & 18.600 & 13.694 & 20.077 & 20.207 & 8.378 & 10.269 & 14.201 & 16.567 \\
\hline & (38.918) & (34.409) & $(40.060)$ & $(40.166)$ & $(27.707)$ & $(30.362)$ & (34.907) & $(37.182)$ \\
\hline \multirow[t]{2}{*}{ Average hours in primary job } & 23.920 & 23.955 & 22.703 & 23.069 & 40.564 & 40.541 & 41.190 & 40.992 \\
\hline & $(7.032)$ & $(7.561)$ & $(7.401)$ & (7.327) & $(4.436)$ & $(4.644)$ & $(5.731)$ & $(5.270)$ \\
\hline \multirow[t]{2}{*}{ Average hours in second job } & 0.704 & 0.845 & 0.925 & 1.110 & 0.125 & 0.075 & 0.136 & 0.108 \\
\hline & $(3.588)$ & (3.888) & $(4.066)$ & $(4.535)$ & $(1.680)$ & $(1.277)$ & $(1.714)$ & $(1.185)$ \\
\hline
\end{tabular}

NOTE - Table reports group means by hours worked, firm size and time period. Standard errors are reported in parentheses. The sample is limited to employees under age 64 with positive net monthly income.

Table 2: Distribution of Usual Weekly Hours (\%)

\begin{tabular}{|c|c|c|c|c|c|c|c|c|c|c|}
\hline & \multicolumn{5}{|c|}{ SSmall firms } & \multicolumn{5}{|c|}{ Large firms } \\
\hline & Above 39 & 39 & $35-39$ & 35 & Below 35 & Above 39 & 39 & $35-39$ & 35 & Below 35 \\
\hline 1999 & 21.49 & 49.02 & 2.25 & 2.46 & 24.78 & 16.44 & 47.43 & 8.66 & 5.48 & 15.88 \\
\hline 2000 & 21.39 & 44.64 & 2.2 & 7.2 & 24.57 & 14.46 & 30.66 & 8.64 & 24.43 & 15.76 \\
\hline 2001 & 21.7 & 41.33 & 3.27 & 11.86 & 21.82 & 13.49 & 18.9 & 8.47 & 35.68 & 13.53 \\
\hline 2002 & 17.35 & 21.54 & 4.75 & 33.73 & 22.62 & 13.38 & 9.99 & 9.71 & 45.42 & 15.42 \\
\hline
\end{tabular}


Table 3: Hours, Wages and Monthly Income

\begin{tabular}{|c|c|c|c|c|c|c|}
\hline & \multicolumn{2}{|c|}{ " Usual Weekly Hours } & \multicolumn{2}{|c|}{ Log Hourly Wage } & \multicolumn{2}{|c|}{ Log Monthly Income } \\
\hline & (1) & (2) & (1) & (2) & (1) & (2) \\
\hline \multirow{2}{*}{ Large firm } & $-0.386 * * *$ & $-0.311 * * *$ & $0.007 * * *$ & $0.009 * * *$ & -0.001 & $0.004^{* * *}$ \\
\hline & $(0.076)$ & $(0.077)$ & $(0.002)$ & $(0.002)$ & $(0.001)$ & $(0.001)$ \\
\hline \multirow{2}{*}{ Large firm*post1999 } & $-0.291 * * *$ & $-0.591 * * *$ & $0.011 * * *$ & $0.019 * * *$ & $0.003 * * *$ & -0.001 \\
\hline & $(0.068)$ & $(0.184)$ & $(0.002)$ & $(0.004)$ & $(0.001)$ & $(0.001)$ \\
\hline \multirow[t]{2}{*}{ Female } & $-0.638 * * *$ & $-1.52 * * *$ & 0.003 & $0.024 * *$ & $-0.009 * * *$ & $-0.011^{* *}$ \\
\hline & $(0.153)$ & $(0.301)$ & $(0.005)$ & $(0.011)$ & $(0.002)$ & $(0.004)$ \\
\hline \multirow[t]{2}{*}{ Married } & 0.016 & 0.054 & 0.005 & $0.016^{* * *}$ & $0.008^{* * *}$ & $0.019 * * *$ \\
\hline & $(0.124)$ & $(0.159)$ & $(0.004)$ & $(0.005)$ & $(0.002)$ & $(0.003)$ \\
\hline \multirow{2}{*}{ Female*married } & $-0.857 * * *$ & $-1.068 * * *$ & $0.025^{* * *}$ & $0.018^{*}$ & -0.004 & $-0.014^{* *}$ \\
\hline & $(0.169)$ & $(0.237)$ & $(0.006)$ & $(0.01)$ & $(0.003)$ & $(0.005)$ \\
\hline \multirow[t]{2}{*}{ Children under 6} & 0.105 & $-0.179 *$ & -0.004 & $0.008^{* *}$ & -0.002 & $0.004 *$ \\
\hline & $(0.126)$ & $(0.085)$ & $(0.003)$ & $(0.003)$ & $(0.001)$ & $(0.002)$ \\
\hline \multirow{2}{*}{ Female*children under 6} & $-0.802 * * *$ & $-0.691 * * *$ & $0.023 * * *$ & 0 & 0.001 & $-0.022 * * *$ \\
\hline & $(0.224)$ & $(0.194)$ & $(0.007)$ & $(0.004)$ & $(0.002)$ & $(0.004)$ \\
\hline \multirow[t]{2}{*}{ Age } & $-0.088^{*}$ & $-0.218 * * *$ & $0.005^{* * *}$ & $0.021 * * *$ & $0.003 * * *$ & $0.015^{* * *}$ \\
\hline & $(0.043)$ & $(0.048)$ & $(0.001)$ & $(0.001)$ & $(0.0003)$ & $(0.001)$ \\
\hline \multirow[t]{2}{*}{ Tenure less than 1 year } & 0.262 & $0.601 * * *$ & $-0.011^{* *}$ & $-0.026 * * *$ & $-0.003 * *$ & $-0.012 * * *$ \\
\hline & $(0.193)$ & $(0.15)$ & $(0.005)$ & $(0.005)$ & $(0.001)$ & $(0.004)$ \\
\hline
\end{tabular}

NOTE - Robust standard errors adjusted for clustering by year/firm size. Hourly wage is monthly wage/(4.33*usual weekly hours). Column (1) shows the results for the sample of employees under age 64 with net monthly income between $10 \%$ below and $10 \%$ above the minimum wage. Column (2) shows the results for the sample of employees under age 64 with net monthly income between $10 \%$ and $80 \%$ above the minimum wage. Regressions include year dummies, region effects, education and age-squared. $* * *$ significant at the $1 \%$ level, ** significant at the $5 \%$ level, * significant at the $10 \%$ level. No. observations: for log hourly wage (1) 12520, (2) 17294; for usual weekly hours (1) 12521, (2) 17296; for log monthly income (1) 13146, (2) 18765. 
Table 4: Dual Job Holdings

\begin{tabular}{ll}
\hline \hline Large firm & $-0.016^{* *}$ \\
Treatment & $(0.007)$ \\
& $-0.081^{* * *}$ \\
Large firm*post1999 & $(0.004)$ \\
& $-0.032^{* * *}$ \\
Treatment*post1999 & $(0.008)$ \\
& $-0.019^{* * *}$ \\
Large firm*treatment & $(0.007)$ \\
& 0.012 \\
Large firm*treatment*post1999 & $(0.007)$ \\
& $0.033^{* * *}$ \\
Female & $(0.008)$ \\
& $0.012^{* *}$ \\
Married & $(0.005)$ \\
& 0.003 \\
Female*married & $(0.002)$ \\
& $-0.025^{* * *}$ \\
Children under 6 & $(0.006)$ \\
& 0.001 \\
Female*children under 6 & $(0.002)$ \\
Age & $-0.009^{* * *}$ \\
Tenure less than 1 year & $(0.003)$ \\
& $0.002^{* * *}$ \\
\hline \hline
\end{tabular}

NOTE - Robust standard errors adjusted for clustering by year/firm size/treatment. Regression includes year dummies, region effects, education, net monthly income and age-squared. No. observations: 49806.

Table 5: Transitions from Large to Small Firms

\begin{tabular}{ll}
\hline \hline Treatment & $-0.017^{* * *}$ \\
& $(0.004)$ \\
Treatment*post1999 & $0.012^{* * *}$ \\
& $(0.003)$ \\
Age & $-0.005^{* * *}$ \\
& $(0.002)$ \\
Tenure less than 1 year & $0.068^{* * *}$ \\
& $(0.006)$ \\
\hline \hline
\end{tabular}

NOTE - Robust standard errors adjusted for clustering by year/treatment. Regression includes year dummies, region effects, education, net monthly income, gender, marital status, an interaction of gender and marital status, number of children under 6 , an interaction of gender and number of children under 6 and age-squared. No. observations: 33234. 
Table 6: Usual Weekly Hours for Workers who Move from Large to Small Firms

\begin{tabular}{ll}
\hline \hline Treatment & 0.275 \\
& $(0.301)$ \\
Treatment*post1999 & $0.535^{*}$ \\
& $(0.298)$ \\
Female & $-0.863^{* * *}$ \\
& $(0.155)$ \\
Married & $0.552^{* * *}$ \\
& $(0.082)$ \\
Female*Married & $-0.714^{* * *}$ \\
& $(0.134)$ \\
Children under 6 & $-0.084^{* *}$ \\
& $(0.036)$ \\
Female*Children under 6 & $-0.958^{* * *}$ \\
& $(0.137)$ \\
Age & $0.188^{* * *}$ \\
& $(0.025)$ \\
Tenure less than 1 year & -0.298 \\
& $(0.217)$ \\
\hline \hline
\end{tabular}

NOTE - Robust standard errors adjusted for clustering by year/treatment. Regression includes year dummies, region effects, education, net monthly income and age-squared. No. observations: 26506.

Table 7: Transitions from Employment to Unemployment

\begin{tabular}{ll}
\hline \hline Large firm & $-0.01^{* * *}$ \\
& $(0.002)$ \\
Large firm*post1999 & $0.013^{* * *}$ \\
& $(0.003)$ \\
Female & -0.001 \\
& $(0.006)$ \\
Married & $-0.013^{* *}$ \\
& $(0.006)$ \\
Tenure less than 1 year & $0.08^{* * *}$ \\
& $(0.005)$ \\
Seasonal contract & $0.096^{*}$ \\
& $(0.045)$ \\
\hline \hline
\end{tabular}

NOTE - Robust standard errors adjusted for clustering by year/firm size. Regression includes year dummies, region effects, education, an interaction of gender and marital status, number of children under 6 , an interaction of gender and number of children under 6 and a quadratic in age. No. observations: 13321. 
Table 8: Transitions from Unemployment to Employment

\begin{tabular}{|c|c|c|}
\hline & log[P(large)/P(unemployed)] & "log[P(small)/P(unemployed)] \\
\hline Unemployed & $\begin{array}{l}-2.664 * * * \\
(0.187)\end{array}$ & $\begin{array}{l}-2.41 * * * \\
(0.205)\end{array}$ \\
\hline Unemployed*post1999 & $\begin{array}{l}1.767 * * * \\
(0.21)\end{array}$ & $\begin{array}{l}1.631^{* * *} \\
(0.209)\end{array}$ \\
\hline Unemployed*unemployed less than a year & $\begin{array}{l}0.583 * * * \\
(0.113)\end{array}$ & $\begin{array}{l}0.471^{* * *} \\
(0.094)\end{array}$ \\
\hline Female & $\begin{array}{l}0.027 \\
(0.085)\end{array}$ & $\begin{array}{l}0.088 \\
(0.13)\end{array}$ \\
\hline Married & $\begin{array}{l}0.852 * * * \\
(0.083)\end{array}$ & $\begin{array}{l}0.72 * * * \\
(0.069)\end{array}$ \\
\hline Female*married & $\begin{array}{l}-0.745^{* * * *} \\
(0.083)\end{array}$ & $\begin{array}{l}-0.535^{* * *} \\
(0.093)\end{array}$ \\
\hline Children under 6 & $\begin{array}{l}-0.069 \\
(0.084)\end{array}$ & $\begin{array}{l}-0.011 \\
(0.082)\end{array}$ \\
\hline Female*children under 6 & $\begin{array}{l}-0.295^{* * *} \\
(0.09)\end{array}$ & $\begin{array}{l}-0.339 * * * \\
(0.105)\end{array}$ \\
\hline Age & $\begin{array}{l}0.084 * * * \\
(0.031)\end{array}$ & $\begin{array}{l}0.053 * * \\
(0.023)\end{array}$ \\
\hline $\begin{array}{l}\text { p-value for equality of coefficients on } \\
\text { unemployed*post1999 }\end{array}$ & & 0.01 \\
\hline
\end{tabular}

NOTE - Robust standard errors adjusted for clustering by year/unemployed in base year. Comparison group is the unemployed. Estimates give the change in the log odds ratio for a one-unit change in the independent variable. Regression includes year dummies, region effects, education and age-squared. No. observations: 14126. 
Table 9: Employment

\begin{tabular}{lll}
\hline \hline & $\log [\mathrm{P}($ large $) / \mathrm{P}($ unemployed) & $\log [\mathrm{P}(\mathrm{small}) / \mathrm{P}($ unemployed)] \\
\hline Post1999 & $0.084^{* * *}$ & $0.068^{* * *}$ \\
& $(0.027)$ & $(0.023)$ \\
Female & $-0.085^{* *}$ & -0.036 \\
& $(0.038)$ & $(0.03)$ \\
Married & $1.072^{* * *}$ & $0.937^{* * *}$ \\
& $(0.034)$ & $(0.028)$ \\
Female* married & $-0.719^{* * *}$ & $-0.459^{* * *}$ \\
& $(0.045)$ & $(0.037)$ \\
Children under 6 & $-0.047^{*}$ & 0.025 \\
& $(0.026)$ & $(0.023)$ \\
Female*children under 6 & $-0.283^{* * *}$ & $-0.389^{* * *}$ \\
& $(0.038)$ & $(0.031)$ \\
Age & $0.131^{* * *}$ & $0.089^{* * *}$ \\
& $(0.007)$ & $(0.006)$ \\
\hline p-value for equality of & & \\
coefficients on post1999 & & \\
\hline \hline
\end{tabular}

NOTE - The comparison group is the unemployed. Estimates give the change in the log odds ratio for a oneunit change in the independent variable. Regression includes year dummies, region effects, education and agesquared. No. observations: 91144. 
Table 10: Satisfaction with Hours of Work

\begin{tabular}{ll}
\hline \hline Year 2001 & $-0.125^{* * *}$ \\
& $(0.022)$ \\
France & $-0.179^{* * *}$ \\
& $(0.052)$ \\
Year 2001*France & 0.017 \\
& $(0.078)$ \\
Union member & $0.175^{* * *}$ \\
& $(0.023)$ \\
Married & $0.062^{* *}$ \\
& $(0.025)$ \\
Female & $0.105^{* * *}$ \\
& $(0.023)$ \\
Age & $-0.021^{* * *}$ \\
& $(0.006)$ \\
Age squared & $0.0004^{* * *}$ \\
& $(0.0001)$ \\
\hline \hline
\end{tabular}

NOTE -Regression includes occupation and household income. No. observations: 9567. 
Figure 1. Annual Hours Worked Per Person Employed

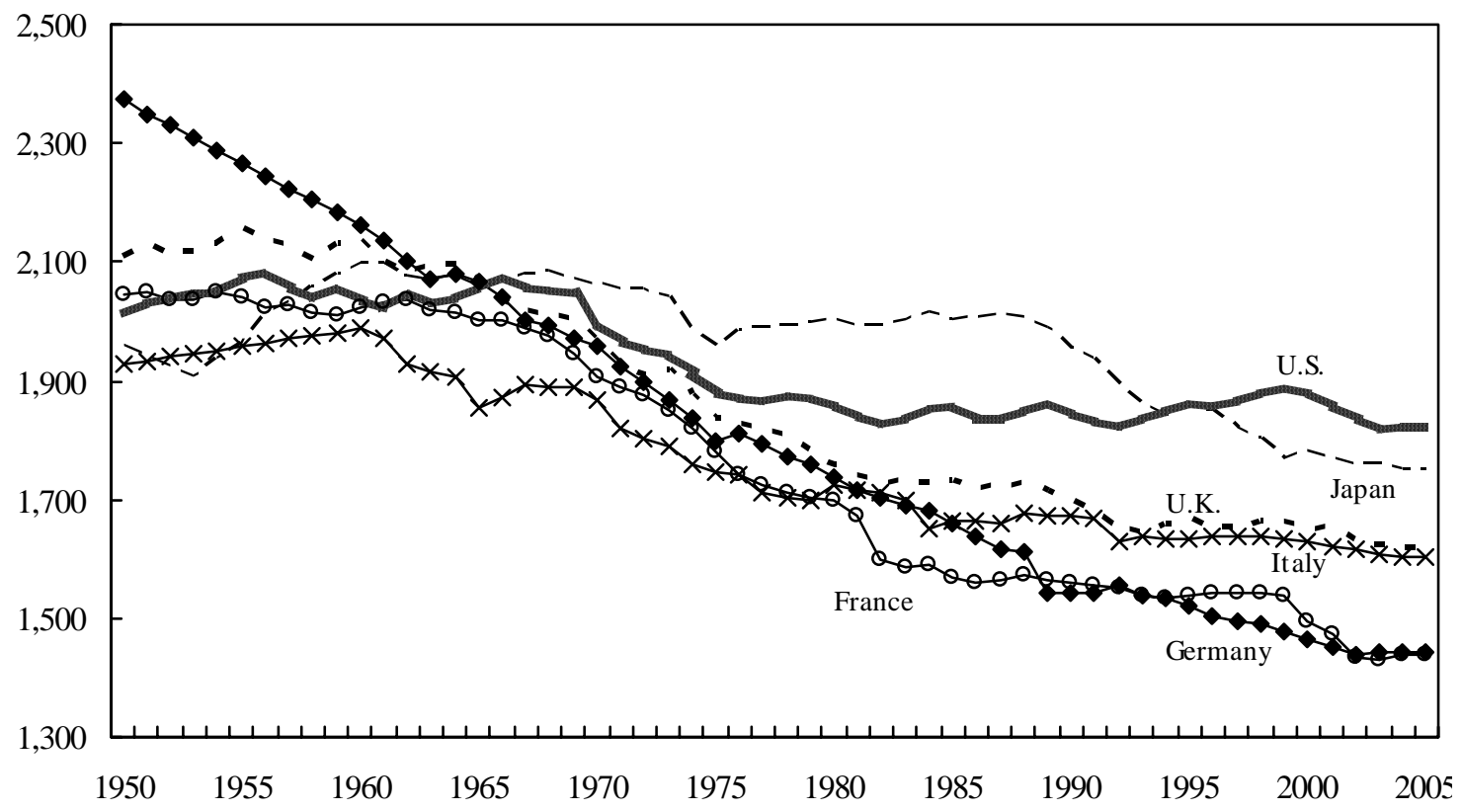

Figure 2. Log Employment Probabilities by Firm Size

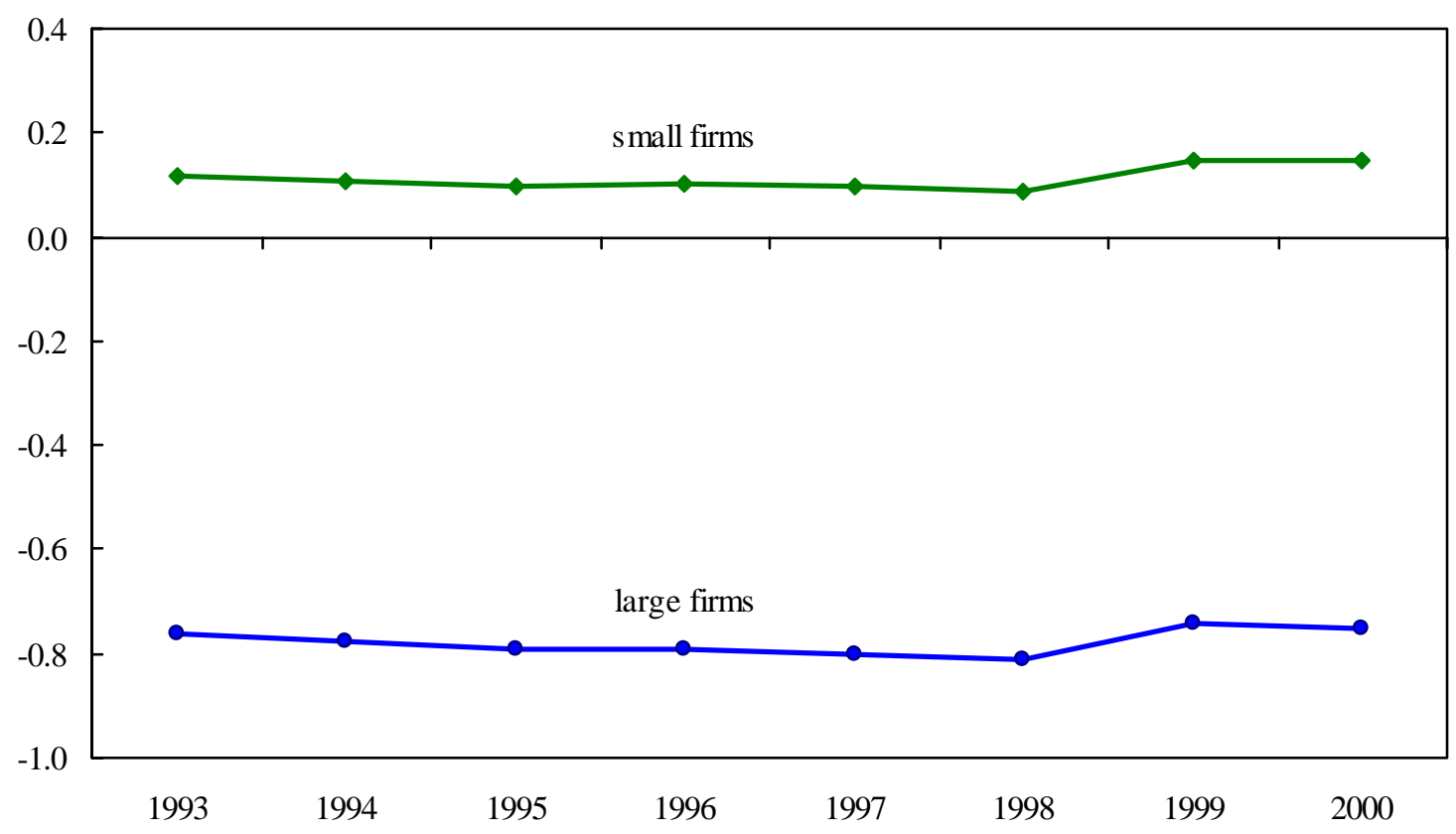




\section{REFERENCES}

Acemoglu, D., and J. Angrist, 2001, “Consequences of Employment Protection? The Case of the Americans with Disabilities Act,” Journal of Political Economy, Vol. 109, No. 5, pp. 915-57.

Alesina, A., E. Glaeser, and B. Sacerdote, 2005, "Work and Leisure in the U.S. and Europe: Why So Different?” NBER Macroeconomics Annual, Vol. 20, Issue 1, pp. 1-64.

Blanchard, O., 2004, “The Economic Future of Europe,” Journal of Economic Perspectives, Vol. 18, No. 4, pp. 3-26.

Cooper, R., and A. John, 1988, “Coordinating Coordination Failures in Keynesian Models,” The Quarterly Journal of Economics, Vol. 103, No. 3, August, pp. 441-63.

Crépon, B., and F. Kramarz, 2002, "Employed 40 Hours or Not Employed 39: Lessons from the 1982 Mandatory Reduction of the Workweek," Journal of Political Economy, Vol. 110, No. 6, pp. 1355-89.

Crépon, B., M. Leclair, and S. Roux, 2005, "RTT, Productivité et Emploi: Nouvelles Estimations sur Donnees d’Enterprises,” Économie et Statistique, Paris: INSEE, No. 376-77, June, pp. 55-89.

Diener, E., and E. Suh, 1999, "National Differences in Subjective Well-Being,” in WellBeing: the Foundations of Hedonic Psychology, ed. by D. Kahneman, E. Diener and N. Schwarz, New York: Russell Sage Foundation, pp. 434-50.

Freeman, R., 1998, “Work-Sharing to Full Employment: Serious Option or Populist Fallacy?” in Generating Jobs: How to Increase Demand for Less-Skilled Workers, ed. by R. Freeman and P. Gottschalk, New York: Russell Sage Foundation, pp. 195-222.

Hunt, J., 1998, “Hours Reductions As Work-Sharing,” Brookings Papers on Economic Activity, No. 1, pp. 339-81. , 1999, “Has Work-Sharing Worked in Germany?” The Quarterly Journal of Economics, Vol. 114, No. 1, pp. 117-48.

Kugler, A., and G. Pica, 2005, “Effects of Employment Protection on Worker and Job Flows: Evidence from the 1990 Italian Reform,” Discussion Paper, Bonn: Institute for the Study of Labor (IZA), No. 1743.

Prescott, E.C., 2004, “Why Do Americans Work So Much More Than Europeans?” Federal Reserve Bank of Minneapolis Quarterly Review, Vol. 28, No. 1, pp. 2-13. 